\title{
HYDROGEOCHEMICAL AND BIOGEOCHEMICAL PROCESSES IN KAFFIØYRA RIVER CATCHMENTS (SPITSBERGEN, NORWAY)
}

\author{
Janina Borysiak ${ }^{1}$, Marek GrZeś2 $^{2}$, Marian Pulina $^{3}$, Grażyna SZPIKOWSKA ${ }^{4}$ \\ ${ }^{1}$ Adam Mickiewicz University in Poznań, Institute of Physical Geography and Environmental Planning, \\ Poznań, Poland \\ ${ }^{2}$ Nicolaus Copernicus University, Department of Hydrology and Water Management, Torun, Poland \\ ${ }^{3}$ Silesian University, Faculty of Earth Sciences, Sosnowiec, Poland \\ ${ }^{4}$ Adam Mickiewicz University in Poznań, Geoecological Station in Storkowo, Poznań, Poland
}

Manuscript received: 1 December 2014

Revised version: 25 January 2015

\begin{abstract}
Borysiak J., Grześ M., Pulina M., SzPiKowsKa G., 2014. Hydrogeochemical and biogeochemical processes in Kaffiøyra river catchments (Spitsbergen, Norway). Quaestiones Geographicae 34(1), Bogucki Wydawnictwo Naukowe, Poznań, pp. 111-124, 4 tables, 11 figs. DOI 10.1515/quageo-2015-0010, ISSN 0137-477X.

AвSTRACT: The paper presents the results of hydrogeochemical and biogeochemical studies in the area of Kaffiøyra river catchments in the ablation season 2004. Vegetation, hydrological regime, mineralization and ionic composition of circulating waters, rate of annual chemical denudation and biogenic $\mathrm{CO}_{2}$ content in soil air in relation to the concentration of dissolved and transported $\mathrm{HCO}_{3}^{-}$ions were documented. The waters represented the type $\mathrm{HCO}_{3}^{-}-\mathrm{SO}_{4}^{2-}-\mathrm{Ca}^{2+}$ $-\mathrm{Mg}^{2+}$. Most of ions showed a good correlation with electrical conductivity. A good correlation between dissolved and transported mass and the discharge was shown. The value of the chemical denudation in non-glacierized catchments of the Kaffiøyra plain was 0.07 and $0.13 \mathrm{t} \mathrm{km}^{-2} \mathrm{~d}^{-1}$, in glacierized catchment $-0,21 \mathrm{t} \mathrm{km}^{-2} \mathrm{~d}^{-1}$. The biogenic $\mathrm{CO}_{2}$ concentrations in tundra soil air ranged from $0.03-0.08 \%$, while the average was $0.046 \%$. The mean rate of $\mathrm{CO}_{2}$ ionic transport was $3 \mathrm{~kg} \mathrm{~d}^{-1}$, while of $\mathrm{HCO}_{3}^{-}-0.63 \mathrm{t} \mathrm{d}^{-1}$. A low correlation between the concentration of biogenic $\mathrm{CO}_{2}$ in soil air and $\mathrm{HCO}_{3}^{-}$was found, which indicates the involvement of other, unexamined bio- and physico-chemical processes.
\end{abstract}

KEY WORDS: Arctic, biogenic $\mathrm{CO}_{2}$, chemical denudation, hydrochemistry, hydrology, tundra vegetation

Address of the corresponding author: Janina Borysiak, Institute of Physical Geography and Environmental Planning, Adam Mickiewicz University in Poznań, Poland, Poznań, Polska, e-mail:jbor@amu.edu.pl

\section{Introduction}

One of the consequences of a general warming trend in air temperature is the evolution of tundra ecosystems in the continuous permafrost zone, as was reported by, among others, Woo et al. (1992), Anisimov and Nelson (1996), Humlum et al. (2003), Kostrzewski et al. (2007), Beylich et al. (2010), or Turner and Marshall (2011), Nowak and Hodson (2014). In the studies on the effects of this global process in the northern hemisphere, the main focus is on the carbon flux from tundra biome (e.g. Christensen 1991) and the role of carbon/nutrient interactions in regulating ecological functions (e.g. Shaver et al. 1992, Christensen et al. 1997, Jonasson et al. 1999). Also, the hydrochemical aspects of chemical denudation generated by cryochemical processes in the glacierized and non-glacierized areas was carried out. The results of these studies were recently published by, among many others, Hodson et al. (2000, 2002), Cooper et al. (2002), Kokelj and Burn (2003), Chmiel et al. (2007, 2011, 2012), Krawczyk and Pettersson (2007), Krawczyk and Bartoszewski (2008), Zwoliński et al. (2008, 2012), Bring and Destouni (2009), Dragon and Marciniak (2010), 
Kuhry et al. (2010), Mazurek et al. (2012) and Szpikowski et al. (2014b). Effects of cryochemical processes were investigated also in the western part of Spitsbergen, in several small glacierized and non-glacierized river catchments: Pulina (1984, 1990), Pulina et al. (1984), Kostrzewski et al. (1989), Bartoszewski et al. (1991); Pulina and Burzyk (2002), Chmiel et al. (2007, 2011, 2012); Krawczyk and Pettersson (2007); Rachlewicz et al. (2007); Szpikowski et al. (2014a, b). Works demonstrate the magnitude of the temporal variability in hydrological and denudation processes. The cited authors documented a large role of cryochemical processes, inter alia, in the mineralization of waters circulating in non-glacierized catchments. They observed the increased mineralization of waters at the end of autumn and relatively high during the first phase of spring outflow and found that one of factors that differentiate the rate of chemical denudation are meteorological conditions. In addition, the role of rain waters and air temperature in mobilizing soluble salts was determined. Kostrzewski et al. (1989) stated that to show the mean values of regional chemical denudation for Spitsbergen, further long-term studies of catchments that are representative for the High Arctic areas with the permafrost are required. The results of such studies can be of much higher significance than only regional.

The aim of the research was to investigate the hydrological and hydrochemical processes in selected river catchments of Kaffiøyra region, as well as their impact on the value of chemical denudation glacierized and non-glacierized catchments including the biotic factors. The objective refers to one of the elements of realized within the framework of the European Science Foundation (ESF) Network SEDIFLUX. Research issues to be investigated within as a part of this Network were outlined by Beylich (2007) and Beylich et al. $(2007,2011)$ and revolve around the analysis of the climate change impact on the landforms in high latitude cold environments.

\section{Study area}

Investigations were conducted in areas of three river catchments (CT-1, CT-2, CT-3) of the Kaffiøyra region (Fig. 1). These catchments are situated in the permafrost zone, at the $\varphi$ N78 ${ }^{\circ} 39^{\prime} 41.4-$ $78^{\circ} 41^{\prime} 13.2^{\prime \prime} / \lambda \mathrm{E} 11^{\circ} 50^{\prime} 54.9^{\prime \prime}-12^{\circ} 08^{\prime} 51.4^{\prime \prime}$. The border of the study area delimited the lateral moraine of Aavatsmarkbreen, peaks: Femhundre (500 $\mathrm{m}$ a.s.1.), Hildtroppen (670 $\mathrm{m}$ a.s.1.) and Prinsen (770 $\mathrm{m}$ a.s.l.) in the Prince Heinrich fjella, Kristine fjella and Gråfjellet.

The geographical environment of Kaffiøyra region was studied (e.g. Gugnacka-Fiedor, Noryśkiewicz 1982a, 1982b; Przybylak, Araźny 2006; Grześ et al. 2009; Jaworski 2010; Sobota, Lankauf 2010; Przybylak et al. 2011; Sobota, Nowak 2012; Dolnicki et al. 2013; Sobota 2013a, 2013b, 2014; Sobota et al. 2013, Stankowski et al. 2013). The study area is under the influence of Atlantic polar-maritime and Arctic circumpolar air masses. The longitudinal orientation of Forlandsundet, the plain adjoins, forces longitudinal winds and movement of air masses. Substantial differences in altitude promote the appearance of foehns, arriving mainly from the east direction. In 1975$2000 \mathrm{y}$., in the period 21.07-31.08, the mean daily air temperature was $5.0^{\circ} \mathrm{C}$, and $45.4 \mathrm{~mm}$ average athmosferic precipitation sum (Przybylak et al. 2011, Sobota 2013b).

In the summer 2004 in Kaffiøyra region, the average daily air temperature was $5.7^{\circ} \mathrm{C}$ (July $6.2^{\circ} \mathrm{C}$, August $5.1^{\circ} \mathrm{C}$; $\min .2 .9^{\circ} \mathrm{C}$, $\left.\max .10 .3^{\circ} \mathrm{C}\right)$. Over the two month-period (01.07-05.09.2004), $160.7 \mathrm{~mm}$ of rain fell in six rainfall events. In July, precipitation was 53\% higher $(87.4 \mathrm{~mm})$ than in August $(57.1 \mathrm{~mm})$. The highest daily rainfall was noted on 30 July $(22 \mathrm{~mm})$, while the highest hourly was $5 \mathrm{~mm}$ on 12 July. The subsequent intensive rainfall occurred at the end of summer - $16 \mathrm{~mm}$ on 03-04 September (results of own measurements).

Meteorological data from the station in Kongsfjorden at Ny-Ålesund (Norwegian Meteorological Institute, http:/ / eklima.met.no; Fig. 2) showed that in the summer 2004, a summer thermal season on the coastal plain started on 11 June and lasted until 8 September (90 days). Atmospheric precipitation during this period amounted to $118.2 \mathrm{~mm}$.

The borders of the investigated catchments were delineated based on a topographic map 1:25,000, prepared by Lankauf (2002). The glacierized catchment CT-3 occupy the area of 7.6 $\mathrm{km}^{2}$ situated at an altitudinal range of $4-770 \mathrm{~m}$ a.s.l., and comprise 5-6 isostatically uplifted marine terraces. Down part of the area is occupied by the lowest terraces, lying between 4 and 80-90 


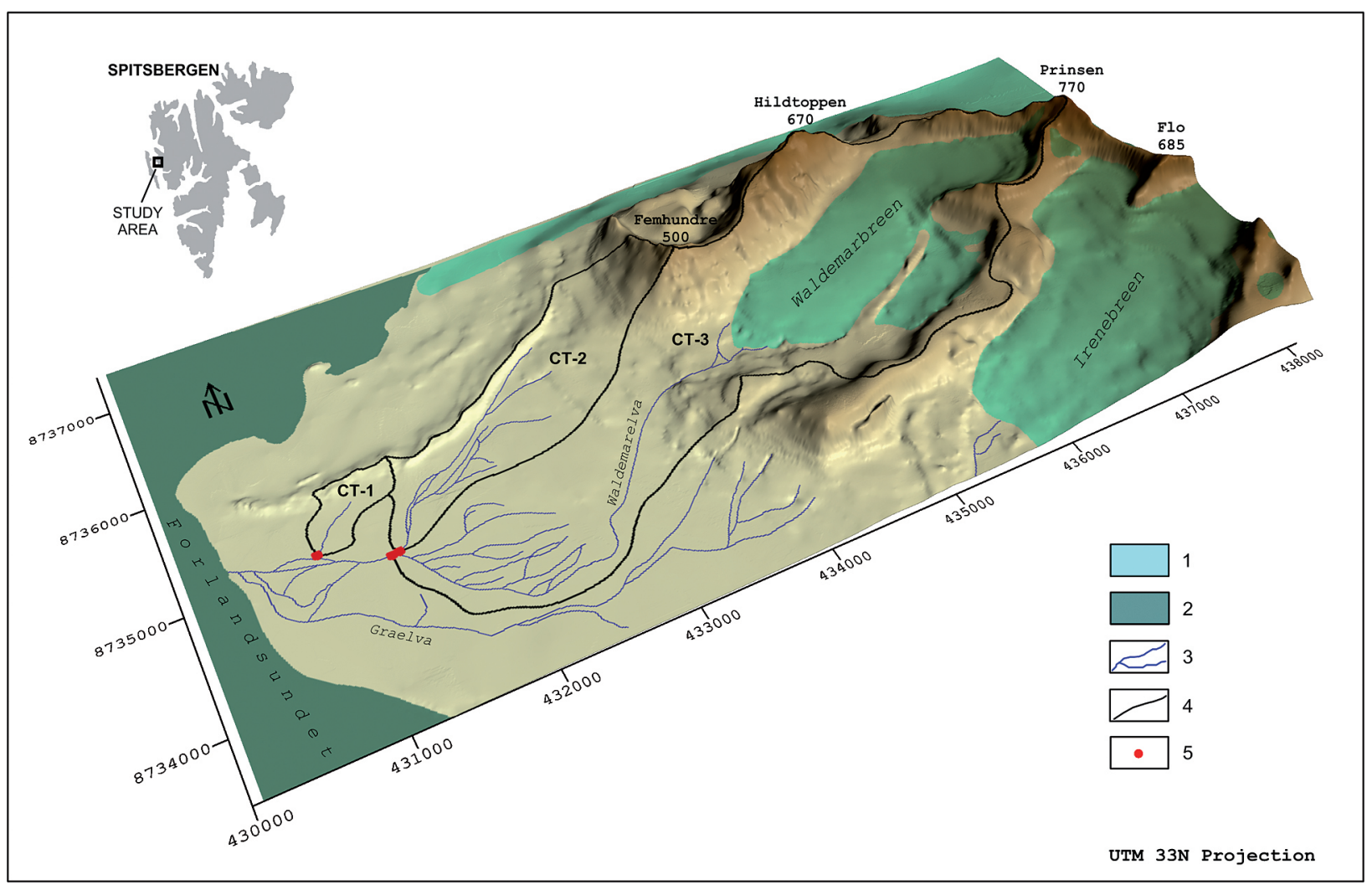

Fig. 1. Investigated river catchments (CT-1, CT-2, CT-3) in the area of Kaffiøyra plain (Oscar II Land, NW Spitsbergen) 1 - glaciers, 2 - sea, 3 - rivers, 4 - catchment borders, 5 - gauging stations Block diagram based on a topographic map 1:25,000, prepared by Lankauf (2002)

$m$ a.s.l.. Two highest terraces are enclosed by cliff walls (made, among others, from limestone), elevated to an altitude of several meters. The upper part of the CT-3 catchment is occupied by Waldemarbreen, between 130-500 $\mathrm{m}$ a.s.l. In the CT-2 non-glacierized catchment $\left(1.9 \mathrm{~km}^{2}\right)$, ice-cored moraine slopes occur. The non-glacierized catchment, marked as CT-1, has only $0.3 \mathrm{~km}^{2}$ and is situated on two low marine terraces. Its upper part comprises the lateral moraine slope of Aavatsmarkbreen.

The eastern, upper region of lowland part of the catchment is built with slope deposits, mainly from the Hecla-Hoek rocks of Precambrian succession (Hjelle et al. 1999). The central and lower parts are made of slope colluvia and marine strata, comprising two outwash fans. The southern fragment includes the recent outwash fan of the Waldemar River, while the northern, the Aavatsmarkbreen outwash fan from the Little Ice Age. The latter forms the northern part of the CT-2 catchment. In the central and bottom parts of the catchment, outwash fans lay on the Tertiary rocks (conglomerates, sandstones and schists), while in the upper, on Precambrian rocks of the
Heckla-Hoek group, with a high content of limestone.

The raised marine terraces are covered with various frost heave structures (raised-soil landforms), from typical tundra polygons and other patterned grounds (like stone circles) on the flat areas to solifluction tongues and stone strips on the sloping terrain.

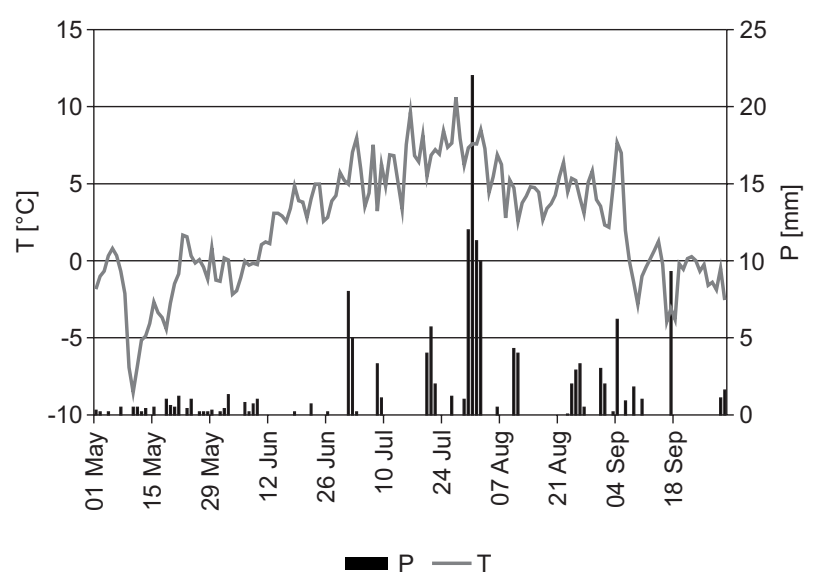

Fig. 2. Air temperature $(\mathrm{T})$ and precipitation $(\mathrm{P})$ from May to September 2004; meteorological station at Ny-Ålesund (Spitsbergen), data from Norwegian Meteorological Institute, http:/ / eklima.met.no 
The catchments are hydrologically active for about 3 months. They are fed by waters from: 1 melting snow cover, 2 - melting ice from the permafrost active layer (in spring and summer) and from an aquifer in the thawed permafrost active layer, 3 - melting ice cores of Aavatsmarkbreen lateral moraine (CT-1 and CT-2), 4 - atmospheric precipitation, 5 - a huge flow from Waldemarbreen (CT-3 catchment).

The studied lowland part is an area of occurrence of phenomena generated by permafrost melting. This results in the appearance of zones connected with the organization of surface and underground watercourses (in the thawed permafrost profile) and formation of seasonal water bodies and permeated areas level edges. The water outflows from active layer occurs in the edges of raised marine terraces, where numerous debris springs are formed. They are accompanied by solifluction covers, often with the series of loamy sediments highly waterlogged. Waters of these springs feed sub-slope parts of the highest terraces, not infrequently forming water flowing in slope gullies.

A characteristic feature of the CT-2 and CT-3 catchments was the presence of extensive and dynamic aquifer in the active layer. In spring and at the beginning of summer, the aquifer provides waters from the melted permafrost and, afterwards, is fed by waters from the mountain slopes, precipitation, Waldemarbreen and melting ice cores of moraines. The catchments differ in the quantity and type of feeding waters. The outflow from the CT-3 catchment indicates a high proportion of water coming from the ablation of

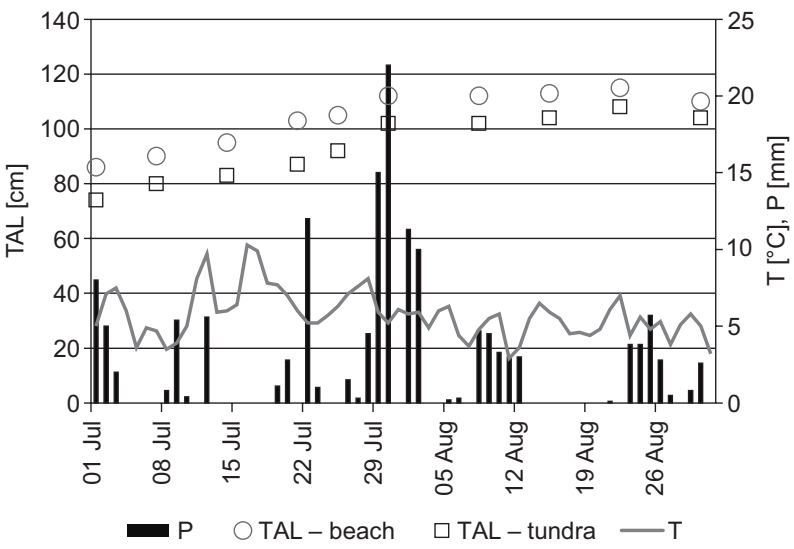

Fig. 3. Thickness of the active layer (TAL) in the area of Kaffiøyra plain in relation to air temperature (T) and precipitation (P) in the period 1.07-5.09.2004 (acc. to Sobota 2013b; Sobota, Nowak 2014)
Waldemarbreen, which constitute mean $55 \%$ of the whole outflow from this catchment (Sobota 2013b).

The thawing of the permafrost starts at the beginning of spring and lasts until the end of summer (Sobota 2013b; Sobota, Nowak 2014). During the period of the study, the thickness of the melted layer was over $100 \mathrm{~cm}$ (108 cm on 22.08.2004). In the lower zone of the CT- 1 catchment thawing ended after 22.08.2004. The highest intensity of this process occurred at the beginning of spring and in the first three weeks of summer. It resulted in melting of the layer of $80 \mathrm{~cm}$ in thickness (Fig. 3).

The soil mapping of Kaffiøyra shows that the area of analysed catchments is covered by: Lithosols, Rankers, Gelic Regosols, Gelic Gleysols and Gelic Cambisols (Plichta 1993, Dziadowiec et al. 1994). Lithosols and Rankers occur in the mountain sub-slope areas. Gelic Cambisols are the most widely distributed. They cover the oldest marine terraces and are generally characterized by good drainage. These soils have developed from gravels, loose sands and weakly clayey sands under the biocoenoses of lichen tundra, dry tundra and deflation tundra. Non-decomposed organic matter lays for a long time, because of poor activity of edaphon. Gelic Gleysols dominate in the lowest parts of the studied area. These soils developed from the highly skeletal light and medium clays, clayey sands and dust deposits. The areas of investigated catchments are characterized by the large areas of Regosols from the skeletal sands and clays. It is covered by a discontinuous organic layer, made mainly of cyanobacteria. The lowland soils can be influenced by marine aerosol brought by storms. Locally, soils are fertilized by animal excrements, mainly of reindeers and birds (Plichta 1.c., Dziadowiec l.c.).

In the bioclimatic division of Arctic, the Svalbard Archipelago (including Kaffiøyra) has been distinguished as the High Arctic region belonging to the group of North Atlantic Ocean (Elvebakk et al. 1999).

\section{Field studies and data analysis}

In the investigated river catchments four experimental plots (1-4) for research on the concentration of biogenic $\mathrm{CO}_{2}$ in soil air were estab- 
lished, $1 \mathrm{~m}^{2}(1 \times 1 \mathrm{~m})$ each. The plot 1 was situated on the youngest marine terrace, 2 and 3 on the second terrace and 4 on the third. This pattern of location reflected the chronosequence of tundra geosuccession stages. The first represented an initial biocoenoses on Gelic Regosol, while the last - tundra on Gelic Cambisol with very well developed bryophyte layer overgrown by Salix polaris.

In the experimental plots 1-4, and also in the area of CT-1, CT-2 and CT-3 catchments real vegetation was examined. Taxonomic and syntaxonomic data were taken from the publication by Hadač (1989) and Elvebakk et Prestrud (eds, 1996). Phytosociological diagnoses were conducted using the Braun-Blanquet method.

In the period 12.07-05.09.2004, hydrological measurements were made in the three permanent hydrometric profiles 1-3, localized in the streams outflowing from the studied catchments, and, intermittently, in over ten other profiles. The study period was extended back to 01.07.2004, based on the statistical calculations, among others, on the data from the Kongsfjorden meteorological station at Ny-Ålesund.

The physical and chemical properties of waters were analysed. The following parameters were measured in the field by the method given by Markowicz and Pulina (1979): temperature, electrical conductivity, bicarbonates concentration, total hardness and $\mathrm{CO}_{2}$ concentration (by titration method). Concentrations of anions $\left(\mathrm{Cl}^{-}\right.$, $\left.\mathrm{NO}_{3}^{-}, \mathrm{SO}_{4}{ }^{2-}\right)$ and cations $\left(\mathrm{Ca}^{2+}, \mathrm{Mg}^{2+}, \mathrm{Na}^{+}\right.$and $\left.\mathrm{K}^{+}\right)$ were determined by ion chromatography (IC). The water samples were collected mainly in the streams leaving the studied catchments and in over ten selected sites in the surface waters and several springs. Nearly 400 measurements were made in 79 samples collected. In the second half of summer and in the autumn 2004, only electric conductivity was measured. In addition, in the experimental plots 1-4 and in several other sites, the concentration of biogenic $\mathrm{CO}_{2}$ in soil air was analysed with the Dräger's pump and ampoules containing an alkaline absorbent, following Pulina and Burzyk (2002), or Pulina et al. (2003).

\section{Results and discussion}

\section{Vegetation in the area of Kaffiøyra river catchments and experimental plots}

Catchments (CT-1, CT-2, CT-3) clearly differ between themselves in the spatial structure of vegetation. In the lower locations, the CT- 1 catchment was covered with a dry lichen tundra with Cetrariella delisei and Saxifraga oppositifolia, while in the higher, by phytocoenoses with a large contribution of Salix polaris, which represent a more advanced stage of tundra development. The vegetation cover of southern slopes of the lateral moraine of Aavatsmarkbreen consists of low-coverage plant communities with Papaverion dahliani Hofmann 1968 em. Elvebakk 1985, accompanied by: Braya purpurascens, Cerastium arcticum, Draba alpina, D. corymbosa, D. subcapitata, Papaver dahlianum, Silene furcata and S. uralensis. The CT-2 catchment is almost totally covered with the various types of tundra phytocoenoses, among others, Luzulion nivalis Nordhagen 1936 and Luzulion arcuatae Elvebakk 1985 all. prov., while the major part of the CT-3 catchment is almost completely devoid of vegetation cover, particularly, within the outwash fan. The CT-2 catchment comprises all marine terraces of the Kaffiøyra plain. The lower terraces, less steeply inclined towards Forlandsundet than those at a higher altitude and reaching up to $20 \mathrm{~m}$ a.s.l., are mainly covered with a dry lichen tundra with the mass contribution of Cetrariella delisei. In some places, a dry lichen tundra alternates with a dry or moderately dry moss tundra with the contribution of vascular plants, not infrequently with Salix polaris. The CT-2 catchment is characterised by the presence of wetlands, including small tundra lakes. In such places, the communities with Cardamino nymanii-Saxifragion foliosae Hadač 1984 have developed, among others, with Cardamine pratensis subsp. polemonioides, Deschampsia alpina, Equisetum scirpoides and Juncus biglumis. In the middle strip of marine terraces (20-40 m a.s.l.), much more steeply inclined and narrow and separated by more distinct old storm ridges, dominates a fresh moss tundra, while a dry lichen tundra is restricted to patterned grounds. Characteristic for this area are 'fruticose and crustose lichen' communities, among others, with Umbilicarion cylindricae Frey 1933 or Xanthorion elegantis Du- 
biel et Olech 1990 all. prov. In fresh habitats, the contribution of bryophytes and vascular plants in phytocoenoses increases. The most frequently observed species include from vascular plants Bistora vivipara, Dryas octopetala, Festuca rubra ssp. arctica, Luzula arctica, L. arcuata subsp. confusa and Pedicularis hirsuta. A typical element of more steeply inclined, older marine terraces are spring moss biocoenoses and snowbed vegetation. In the highly elevated part of the CT-2 catchment, at the foot of Femhundre, on more stable ground, a lichen tundra has developed on the dryer soils and moss tundra on more humid. The wide subslope zone of Femhundre is particularly rich in springs. In this zone, widespread species include: Bistora vivipara, Cerastium arcticum, C. regelii, Draba alpina, Dryas octopetala, Luzula arctica, Minuartia rubella, M. stricta, Oxyria digyna, Poa alpina subsp. vivipara, Salix polaris, Saxifraga cespitosa, S. oppositifolia and Silene acaulis. The aforementioned plants occurred, among others, in the communities with Papaverion dahliani Hofmann 1968 em. Elvebakk 1985, Ranunculo-Oxyrion Nordhagen 1936 and Drepanoclado-Poion alpinae Hadač 1946. In terms of vegetation, the CT-3 catchment is similar to the CT-2. The CT-3 is distinct in its isolation from the Aavatsmarkbreen lateral moraine, thus, the absence of biocoenoses of this geosystem. Another

Table 1. Floristic structure of tundra phytocoenoses at the experimental plots 1-4 in the area of Kaffiøyra plain (Oscar II Land, Spitsbergen)

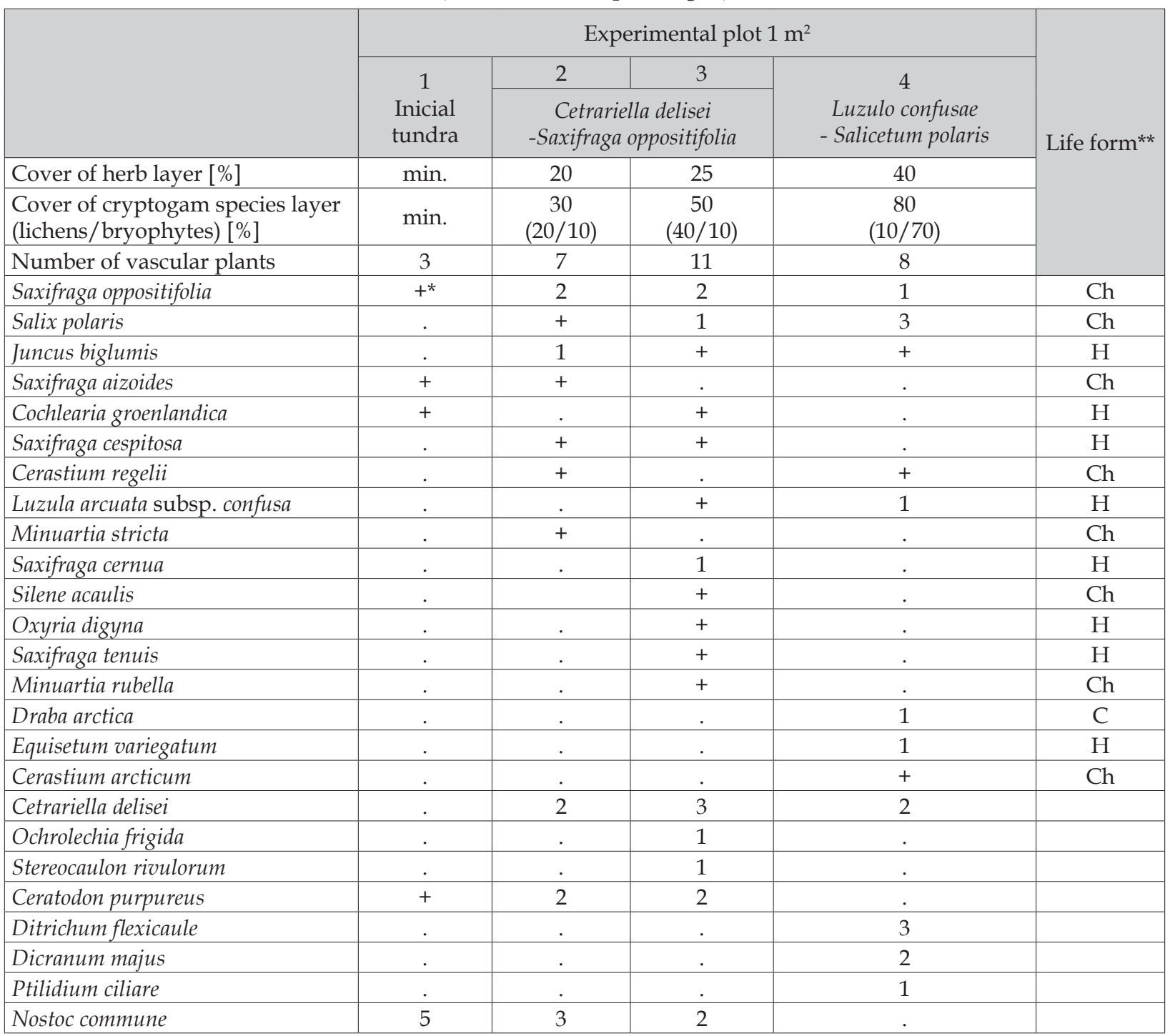

*Phytosociological Braun-Blanquet scale of vegetation cover: + - one or a few individuals covering a small area; $1-\leq 5 \%$ of the plot, $2-2-25 \%, 3-26-50 \%, 4-51-75 \%, 5-76-100 \%$;

** Life form acc. to Raunkiaer's classification: C - cryptophyte, $\mathrm{Ch}$ - chamaephyte, $\mathrm{H}$ - hemicryptophyte 
distinctive feature of this catchment is an extensive sandur plain, only partially covered by vegetation, i.e., a lichen tundra with Catraliella delisei. In this catchment, reindeers consistently feed and birds are present. Assumingly, as a result of soil fertilization with excrements of these animals, nitrophilous Cochlearia groenlandica and Saxifraga cernua were noted more frequently than in other areas. Floristic structure of tundra phytocoenoses at the experimental plots 1-4 was documented in Table 1.

\section{Hydrological characteristics of Kaffiøyra river catchments}

The flow rate in the discharging waters from the two catchments (CT-1 and CT-2) depended primarily on the precipitation and, secondarily, the air temperature, which played an important role at the beginning and end of summer. Five or six flow culminations were observed, related to high rainfall (Figs 4-5). During these surges, maximal discharges were about $60 \mathrm{dm}^{3} \mathrm{~s}^{-1}$ in the

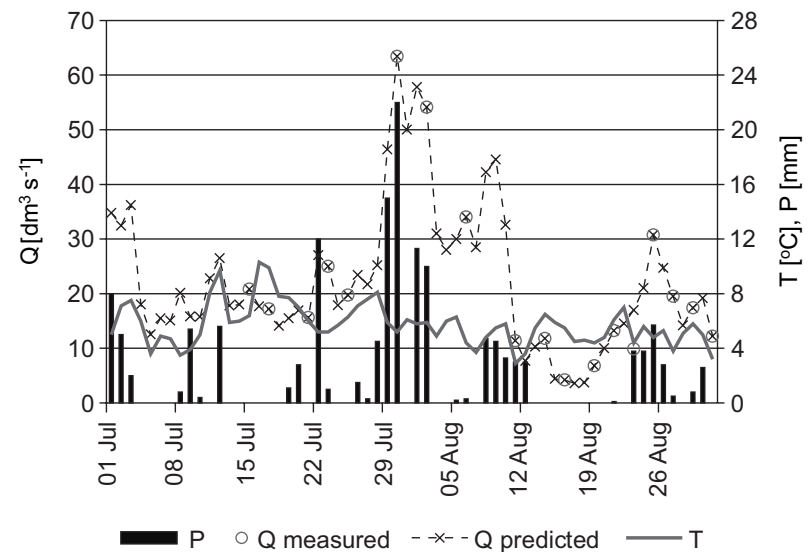

Fig. 4. Discharge $(\mathrm{Q})$ in the stream leaving the CT-2 study catchment in relation to air temperature $(\mathrm{T})$ and precipitation $(\mathrm{P})$ in the period 1.07-5.09.2004
CT-2 catchment (15 times higher than the low water levels) and $390 \mathrm{dm}^{3} \mathrm{~s}^{-1}$ (3 times higher) in the CT-3 catchment (Table 2). Such small fluctuations of discharge in the CT-3 catchment result from the continuous inflow from Waldemarbreen. The dynamics of runoff from the Waldemar River catchment and the share of different types of runoff alimentation have been described in numerous papers from the Kaffiøyra region (e.g. Szczepanik 1993; Brykała, Araźny 2010; Sobota, Nowak 2012; Sobota 2013a, 2013b, 2014). Flow changes reflect the general trend of changes in air temperature. The influence of rainfall is limited to periods with greater total rainfall (Sobota 2012).

The amount of water circulating in the CT-2 catchment for 67 days in 2004 was estimated at 1075 thousand $\mathrm{m}^{3}$. It comprised rainfall water (340 thousand $\mathrm{m}^{3}$ ) and water discharging from the aquifer in the permafrost $\left(735\right.$ thousand $\left.\mathrm{m}^{3}\right)$. The outflow of waters from this catchment, measured in the stream leaving the catchment, was low $(70.1 \mathrm{~mm})$ and amounted to $44 \%$ of precipitation.

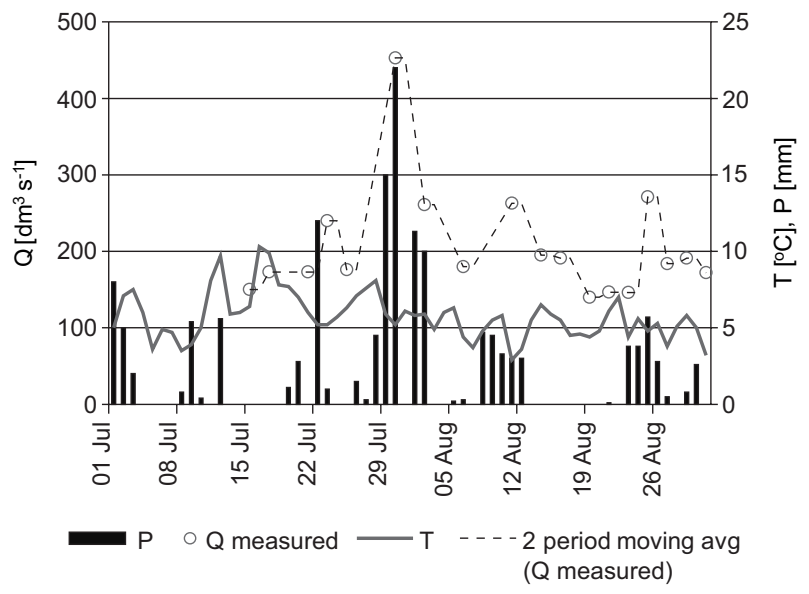

Fig. 5. Discharge (Q) in the stream of the CT-2 + CT-3 study catchments in relation to air temperature $(\mathrm{T})$ and precipitation $(\mathrm{P})$ in the period 1.07-5.09.2004

Table 2. Meteorological and hydrological characteristics of the investigated river catchments in the area of Kaffiøyra plain (Spitsbergen) in the period 01.07-05.09.2004

\begin{tabular}{|c|c|c|c|c|c|c|c|}
\hline \multirow{3}{*}{ Catchment } & \multirow{3}{*}{$\begin{array}{l}\text { Hydrometric } \\
\text { profile }\end{array}$} & \multirow{2}{*}{ Precipitation } & \multicolumn{3}{|c|}{ Discharge } & \multirow{2}{*}{\multicolumn{2}{|c|}{ Outflow }} \\
\hline & & & mean & $\min$ & $\max$ & & \\
\hline & & $\mathrm{mm}$ & \multicolumn{3}{|c|}{$\mathrm{dm}^{3} \mathrm{~s}^{-1}$} & $\mathrm{~mm}$ & $\begin{array}{c}\% \\
\text { of precipitation }\end{array}$ \\
\hline $\begin{array}{c}\text { CT-1 } \\
0.3 \mathrm{~km}^{2}\end{array}$ & $\begin{array}{l}\text { N 78040'14.21" } \\
\text { E } 11^{\circ} 50^{\prime} 54.87^{\prime \prime}\end{array}$ & \multirow{3}{*}{160.7} & 1.6 & 0.2 & 5.0 & 30.9 & 19 \\
\hline $\begin{array}{c}\text { CT-2 } \\
1.9 \mathrm{~km}^{2}\end{array}$ & $\begin{array}{l}\text { N 78 } 40^{\circ} 07.75^{\prime \prime} \\
\text { E } 11^{\circ} 52^{\prime} 18.52^{\prime \prime}\end{array}$ & & 23.0 & 4.2 & 63.4 & 70.1 & 44 \\
\hline $\begin{array}{c}\text { CT-3 } \\
7.6 \mathrm{~km}^{2}\end{array}$ & $\begin{array}{l}\text { N 78 } 78^{\circ} 0^{\prime} 07.37^{\prime \prime} \\
\text { E } 11^{\circ} 52^{\prime} 09.55^{\prime \prime}\end{array}$ & & 198.0 & 129.0 & 390.0 & 150.8 & 94 \\
\hline
\end{tabular}


In the CT-3 catchment, the amount of circulating water was several times higher, because it was fed mainly by waters flowing from Waldemarbreen, through infiltration into the extensive outwash fan. The amount of these waters amounted to $94 \%$ of precipitation and the outflow from this catchment, estimated at 1146 thousand $\mathrm{m}^{3}(150.8$ $\mathrm{mm})$, was over 8 times higher than from the CT-2 catchment (133 thousand $\mathrm{m}^{3}$ ). The CT-1 catchment was characterized by the low outflow (30.9 $\mathrm{mm}$ ) at the level of $19 \%$ of precipitation.

\section{Hydrochemical characteristics of Kaffiøyra river catchments}

During the research season, two basic types of waters circulated in the investigated catchments. Waters feeding the catchments showed a very low mineralization $\left(20-40 \mathrm{mg} \mathrm{dm}^{-3}\right.$ ). Waters from the thawing permafrost and those that infiltrated into the emptying permafrost active layer, showed comparatively high mineralization (Table 3). These waters represented the hydrogeochemical type (Szczukariew-Prikłoński classification in: Macioszczyk, Dobrzyński 2007): $\mathrm{HCO}_{3}^{-}-\mathrm{SO}_{4}^{2-}-\mathrm{Ca}^{2+}-\mathrm{Mg}^{2+}$, with a small $\mathrm{Cl}^{-}, \mathrm{Na}^{+}$and $\mathrm{K}^{+}$content, not exceeding a few $\mathrm{mg} \mathrm{dm}^{-3}$ (Figs 6-7). The genesis of water ionic composition is connected with the dissolving of carbonate and sulfate rocks that occur in the metamorphic series from the Precambrian Hecla-Hoeck succession and in Tertiary sediments. The content of $\mathrm{Cl}^{-}$is considerably low. This indicates a small influence of marine aerosols on the ionic content of waters, resulting from the specific atmospheric circulation. Waters were

Table 3. Physical and chemical properties of water draining the investigated river catchments in the area of Kaffiøyra plain (Spitsbergen) in the period 1.07-5.09.2004

\begin{tabular}{|c|c|c|c|c|c|c|c|c|c|c|c|}
\hline \multirow{4}{*}{$\begin{array}{l}\text { Catch- } \\
\text { ment }\end{array}$} & \multicolumn{5}{|c|}{ Physico-chemical properties (mean values) } & Mineraliza- & \multicolumn{4}{|c|}{ Ionic transport } & \multirow{3}{*}{$\begin{array}{c}\text { Total ionic } \\
\text { load }\end{array}$} \\
\hline & \multirow{2}{*}{$\mathrm{C}_{25}$} & \multirow{2}{*}{$\mathrm{TH}$} & \multirow{2}{*}{$\mathrm{HCO}_{3}^{-}$} & \multirow{2}{*}{$\mathrm{Cl}^{-}$} & \multirow{2}{*}{$\mathrm{CO}_{2}$} & \multirow{2}{*}{$\begin{array}{c}\text { tion } \\
\text { calculating } \\
\text { from } C_{25}\end{array}$} & \multirow{2}{*}{ As } & \multicolumn{3}{|c|}{ Ad } & \\
\hline & & & & & & & & avg & $\min$ & $\max$ & \\
\hline & $\mu \mathrm{S} \mathrm{cm} \mathrm{cm}^{-1}$ & $\begin{array}{c}\text { meq } \\
\mathrm{dm}^{-3} \\
\mathrm{CaCO}_{3}\end{array}$ & \multicolumn{2}{|c|}{ meq $\mathrm{dm}^{-3}$} & $\begin{array}{c}\mathrm{mg} \\
\mathrm{dm}^{-3}\end{array}$ & $\mathrm{mg} \mathrm{dm}{ }^{-3}$ & $\mathrm{~g} \mathrm{~s}^{-1}$ & \multicolumn{3}{|c|}{$t d^{-1}$} & $\mathrm{t} \mathrm{km}^{-2} \mathrm{~d}^{-1}$ \\
\hline CT-1 & 401 & 4.69 & 3.53 & 0.49 & 0.5 & 249 & 0.4 & 0.034 & 0.003 & 0.122 & 0.115 \\
\hline CT-2 & 299 & 3.30 & 2.51 & 0.18 & 0.7 & 185 & 4.3 & 0.368 & 0.085 & 2.365 & 0.194 \\
\hline CT-3 & 233 & 2.61 & 2.24 & 0.17 & 0.6 & 144 & 28.5 & 2.463 & 1.192 & 5.459 & 0.326 \\
\hline
\end{tabular}

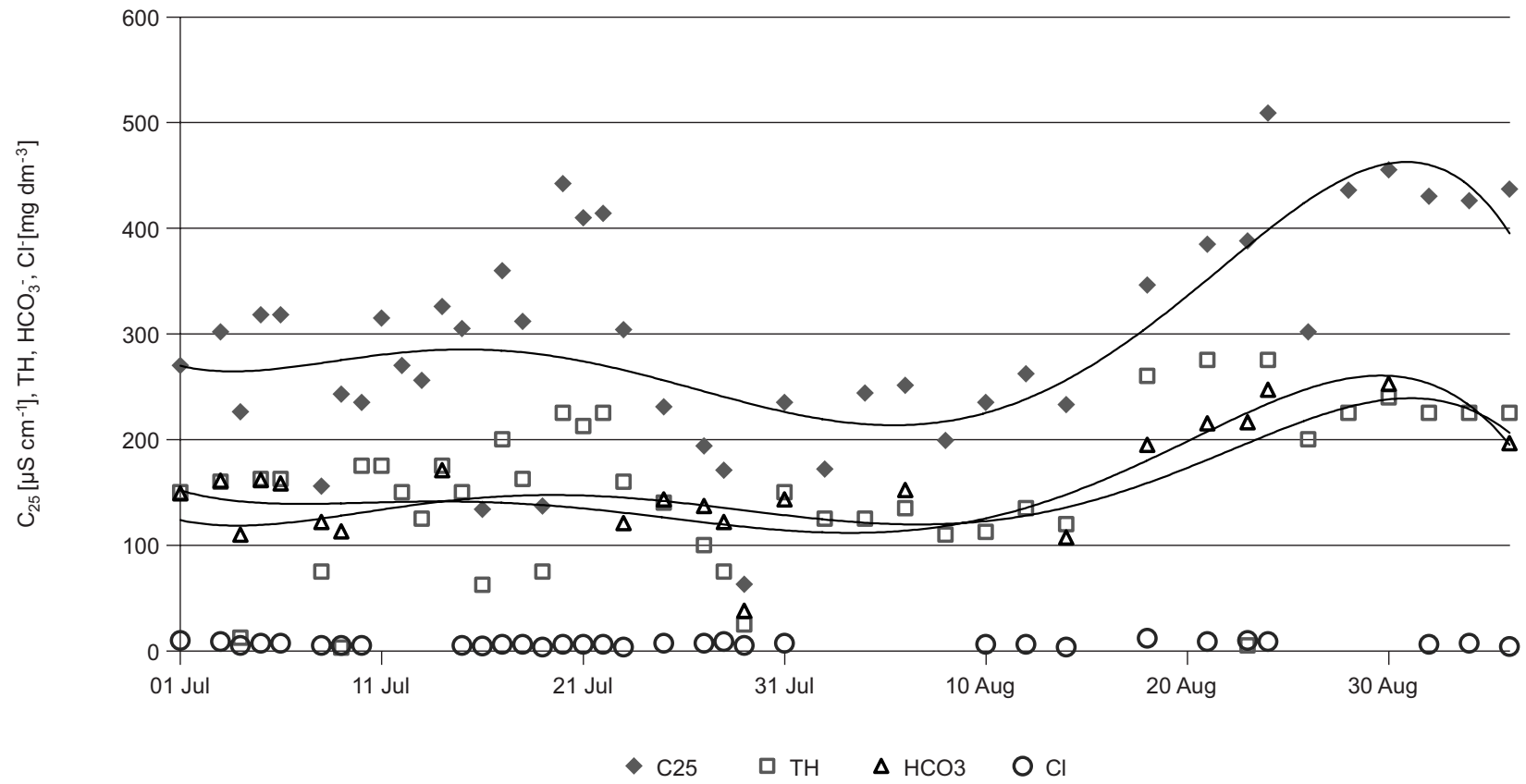

Fig. 6. Electrical conductivity (C25), concentration of $\mathrm{Cl}^{-}$and $\mathrm{HCO}_{3}^{-}$, and total hardness (TH) in streams of CT-2 catchment in the period 1.07-5.09.2014 


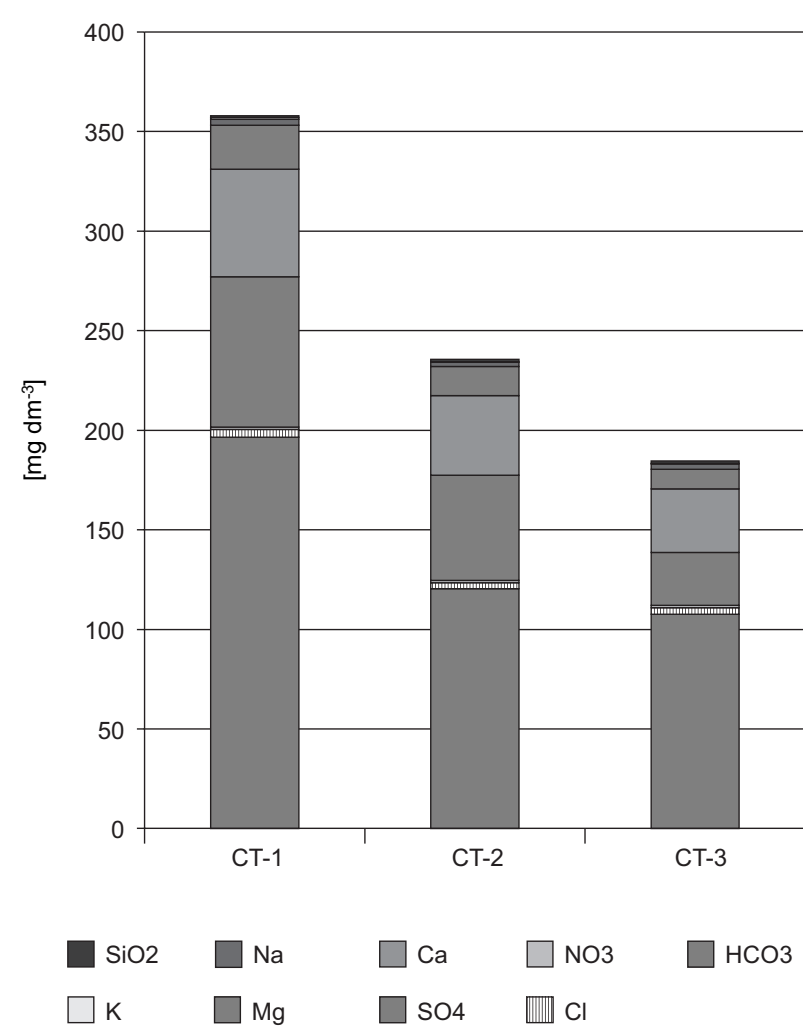

Fig. 7. Water ionic composition in streams leaving the study catchments: CT-1, CT-2 and CT-3; 6 August 2004

characterised by specific interionic interactions. Among others, most of ions showed (Fig. 8) a good correlation with electrical conductivity $\left(R^{2}\right.$ exceeded 0.4 for $\mathrm{HCO}_{3}{ }^{-}$, and 0.9 for $\mathrm{TH}$ ). However, such correlation was not observed between electrical conductivity and concentration of $\mathrm{Cl}^{-}$. This is explicable, considering that the concen- tration of $\mathrm{Cl}^{-}$was found to be at the level of a hydrochemical background.

During the research season, waters with the lowest mineralization occurred in the place of inflow of waters from the melting of Waldemarbreen, and in those seasonal surface water bodies that were fed directly by precipitation. The highest mineralization was found in the springs at the foot of Femhundre, situated in the upper part of the CT-2 catchment and in the outflows from under the Aavatsmarkbreen lateral moraine. The water outflows from the three studied catchments differed from one another to a small degree in terms of ion composition, while they clearly varied in their mineralization. The CT-1 catchment waters showed the highest mean mineralization $\left(249 \mathrm{mg} \mathrm{dm}^{-3}\right)$, while in the CT-3 catchment the lowest $\left(144 \mathrm{mg} \mathrm{dm}^{-3}\right)$. The stream leaving the CT-2 catchment had mineralization $185 \mathrm{mg} \mathrm{dm}^{-3}$. Such substantial dissimilarities resulted from the differences in the mineralization degree of their feeding waters. The lowest mineralization in the CT-3 catchment was related to the inflow of poorly mineralized waters from the melting of Waldemarbreen, while the high mineralization in the CT- 1 catchment was due to the highly mineralized waters flowing from under the Aavatsmarkbreen lateral moraine.

In all measurement points, some variation in the water mineralization degree over time was observed. The saturation of water with mineral salts increased at the end of summer season (Fig.

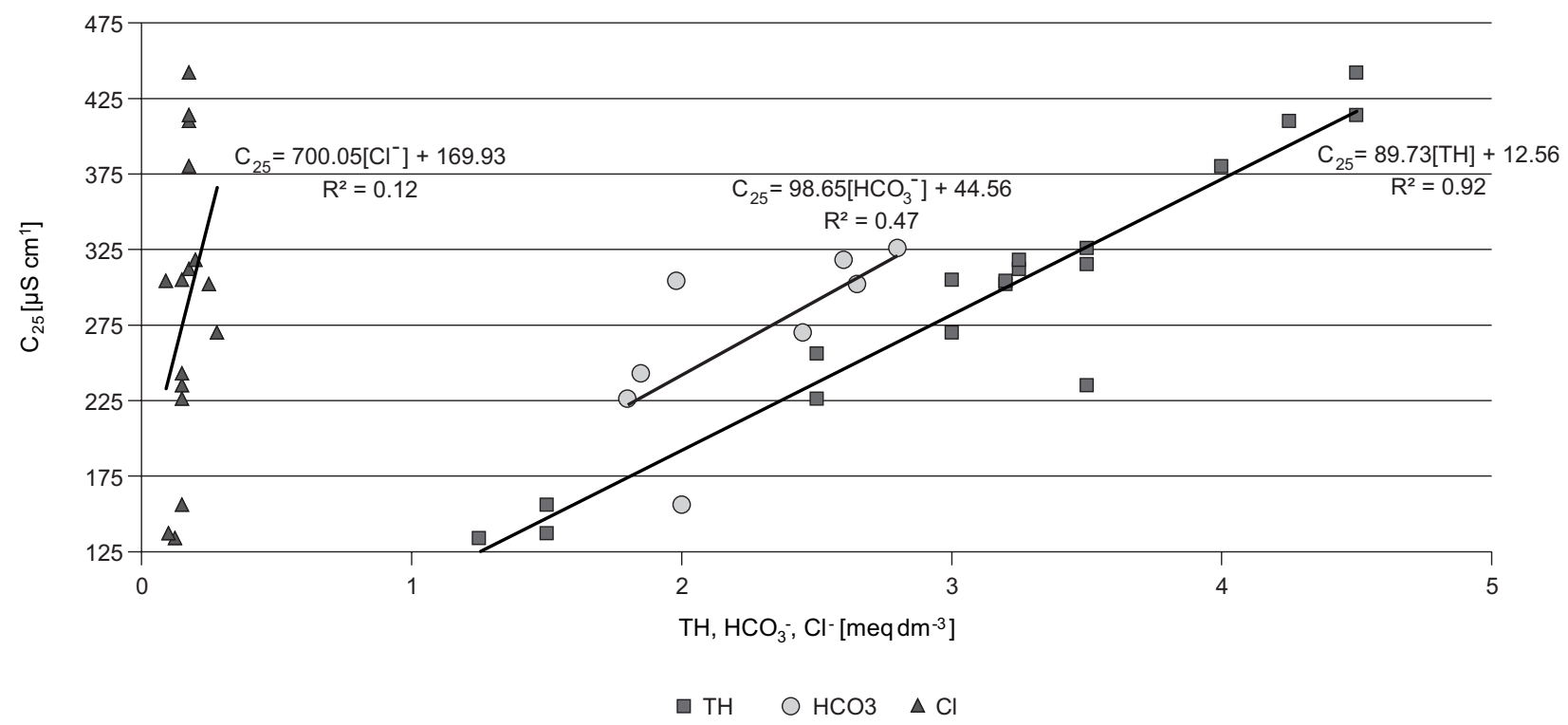

Fig. 8. Electrical conductivity $(\mathrm{C} 25)$ in the stream of the CT-2 study catchment as a function of concentration of $\mathrm{Cl}^{-}$and $\mathrm{HCO}^{3-}$ and total hardness (TH) 


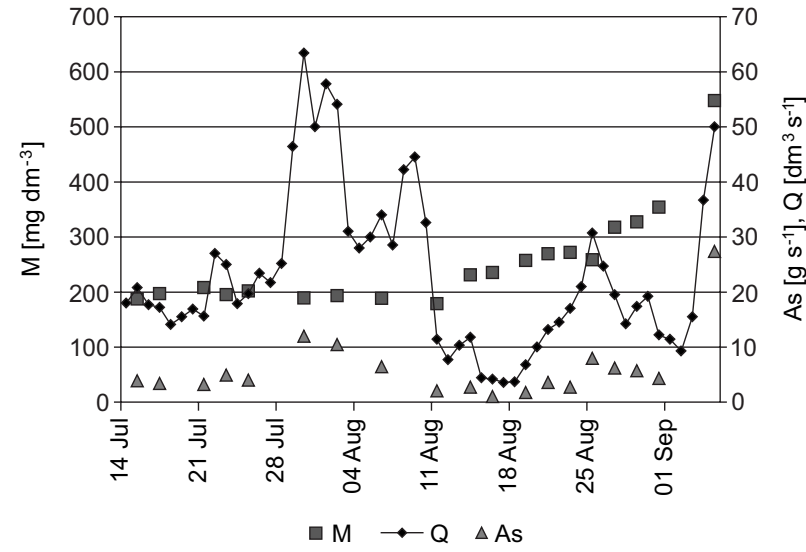

Fig. 9. Water mineralization (M) and ionic transport (As) in the stream leaving the CT-2 study catchment in relation to flow (Q) in the period 14.07-5.09.2004

9). Presumably, this was connected among other things with some cryochemical processes. A similar conclusion was drawn by Pulina et al. (1984) and Pulina (1984) in the non-glacierized Fugleberget basin $\left(1.3 \mathrm{~km}^{2}\right)$, situated on the northern shore of Hornsund Fiord (SW Spitsbergen). The effect of cryochemical processes was seen in the changes of the water mineralization in the unglaciated areas with permafrost of the Wydrzyca catchment (Calypsostranda region, SW Spitsbergen) $-1.3 \mathrm{~km}^{2}$ (Bartoszewski et al. 1991, Chmiel et al. 2011), and the Dynamiskbekken basin (Petuniabukta region, Central Spitsbergen) $-1,43 \mathrm{~km}^{2}$ (Kostrzewski et al. 1989, Szpikowski et al. 2014a) .

\section{Biogenic $\mathrm{CO}_{2}$ concentration in the tundra soil air and its role in ion transport}

The measured concentrations of biogenic $\mathrm{CO}_{2}$ in the tundra soil air ranged from $0.03-0.08 \%$, with the average $0.046 \%$, i.e., ranged from the level similar to the atmospheric content of $\mathrm{CO}_{2}$ (about $0.03 \%$ ) to almost 3 times higher (Fig. 10).

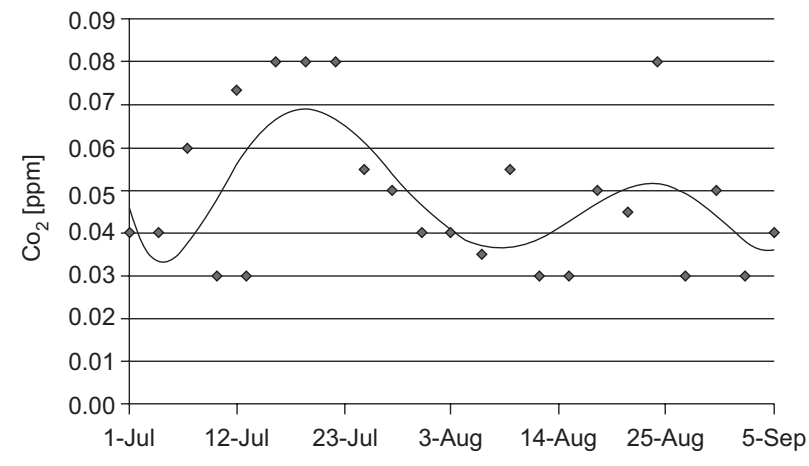

Fig. 10. Concentration of biogenic $\mathrm{CO}_{2}$ in soil air of tundra biocoenoses in the area of Kaffiøyra plain in the period 1.07-5.09.2004; trend of the 6th order polynomial
The graphical data distribution is similar to the results of free $\mathrm{CO}_{2}$ distribution in the waters of studied catchments and inversely proportional to the $\mathrm{HCO}_{3}{ }^{-}$concentration in these waters. It is explicable, because during the process of carbonate rocks dissolving, the higher content of $\mathrm{HCO}_{3}^{-}$ requires the higher level of $\mathrm{CO}_{2}$. An additional confirmation of maximal use of $\mathrm{CO}_{2}$ in this process is a low content of free $\mathrm{CO}_{2}$ in the waters of catchments (0.4-1.2 $\left.\mathrm{mg} \mathrm{dm}^{-3}\right)$, close to the atmospheric partial pressure of $\mathrm{CO}_{2}$ (Fig. 11). However, worth of noting are high concentrations of $\mathrm{HCO}_{3}^{-}$ (122-216.5 $\mathrm{mg} \mathrm{dm}^{-3}$, with the average $171.7 \mathrm{mg}$ $\left.\mathrm{dm}^{-3}\right)$, which indicates a high content of initial $\mathrm{CO}_{2}$. These levels correspond to the air $\mathrm{CO}_{2}$ concentration within the range $0.2 \%-0.5 \%$, which in terms of the free $\mathrm{CO}_{2}$ content in water would correspond to a few $\mathrm{mg} \mathrm{dm}^{-3}$. Concentration of biogenic $\mathrm{CO}_{2}$ in the tundra soil air of the Kaffiøyra plain does not confirm such high water $\mathrm{CO}_{2}$ concentration, which may suggest contribution of other, more efficient source of $\mathrm{CO}_{2}$. The lack of high correlation between the concentration of biogenic $\mathrm{CO}_{2}$ in soil air and $\mathrm{HCO}_{3}^{-}$concentration in waters, but with good correlation between the $\mathrm{CO}_{2}$ and $\mathrm{HCO}_{3}^{-}$ion runoff, may also confirm such assumption.

The rate of $\mathrm{CO}_{2}$ ion transport in the studied catchments was very low. It ranged from $0-12,1$ $\mathrm{kg} \mathrm{d}^{-1}$, with the average $3 \mathrm{~kg} \mathrm{~d}^{-1}$, as compared to $\mathrm{HCO}_{3}$, which amounted to $0,022-2 \mathrm{t} \mathrm{d}^{-1}$, with the average $0,63 \mathrm{t} \mathrm{d}^{-1}$. These facts clearly confirm a weak correlation between the concentration of biogenic $\mathrm{CO}_{2}$ in soil air and $\mathrm{HCO}_{3}^{-}$, which indicates that some other, unexamined bio- and physical-chemical processes must be involved.

The measured concentrations $0.03-0.08 \%$ are three times lower than those found by Pulina et al. (2003), $0.1 \%$, max. $0.3 \%$, in the non-glacierized Fugleberget catchment (SW Spitsbergen) situated within the area of metamorphic and carbonate rocks and covered by rich tundra. The soils in this catchment produced several times more biogenic $\mathrm{CO}_{2}$ than is present in the atmosphere. For instance, in Central Europe, $\mathrm{CO}_{2}$ concentrations in the agricultural soils of Germany and Hungary may be as much as $2-3 \%$ in the middle of the vegetation growth season (Gerstenhauer 1969, Jakucs 1977), i.e. it is ten times higher than that in the tundra of Spitsbergen. In the tropical zone in southern China, Song and Fuyuan (2001) record- 


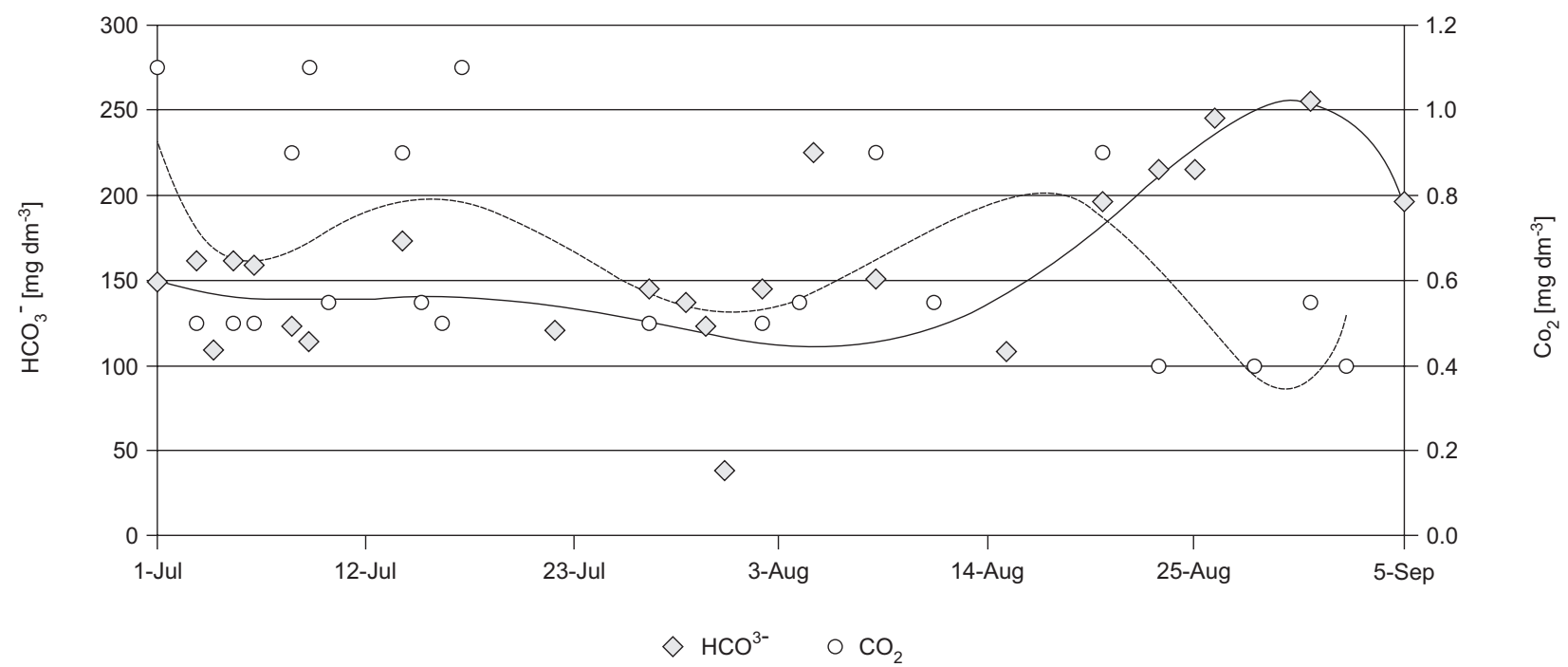

Fig. 11. Concentration of $\mathrm{HCO}_{3}$ and $\mathrm{CO}_{2}$ in streams of study river catchments, trends of the 5 th and 6 th order polynomial the period 1.07-5.09.2004

ed even $5 \%$ of soil $\mathrm{CO}_{2}$ content under eucalyptus trees in the karstic depression areas. Mean rates of soil respiration vary widely within different types of vegetation. The lowest rates $(60 \pm 6 \mathrm{~g} \mathrm{C}$ $\mathrm{m}^{-2} \mathrm{yr}$ ) occur in the tundra biome, the highest (1260 $\pm 57 \mathrm{~g} \mathrm{C} \mathrm{m}^{-2} \mathrm{yr}$ ) in tropical moist forests (Raich, Schlesinger 1992).

\section{Ionic transport and chemical denudation}

The CT-2 catchment differs from the CT-3 catchment in terms of the quantity of dissolved and transported mass of salts. From the CT-2 catchment $0.4 \mathrm{t} \mathrm{d}^{-1}$ was carried in the summer 2004, while from the CT-3 catchment nearly 2.5 $\mathrm{t} \mathrm{d}^{-1}$. The latter was fed by the Waldemarbreen waters infiltrating into the outwash fan, on which the major part of the catchment is situated. The amount of these waters constitutes 30-77\% (average $55 \%$ ) of the total quantity of outflowing waters (Sobota 2013b). For the small non-glacierized CT-1 catchment the salt transport rate was $0.034 \mathrm{t} \mathrm{d}^{-1}$.

The mean daily load of dissolved material transported from the unit of catchment area was calculated ('Total' in Table 4) in the ablation season 2004. The values of flow and constituent concentration in the hydrometric profiles closing the catchments were taken into account. For each catchment, chemical denudation was calculated, including non-denudation ionic components in the loads of dissolved material, similarly like in the study by Sharp et al. (1995), and Hodson et al. (2000). The quantitative contribution of rock, atmospheric and sea components was determined (Table 4). In case of sea ions, it was accepted (following Sharp et al. 1995) that the total load of chloride ions carried from the catchment comes from sea spray. The contribution of other sea ions can be calculated based on the ionic equivalent ratios calculated from the global mean seawater composition (Stumm, Morgan 1996). Among the constituents of atmospheric origin, wet atmospheric deposition was included, based on the total precipitation in Kaffiøyra in the study period and ionic content of rainfall water in the Petuniabukta region, situated in the central part of Spitsbergen (Szpikowski et al. 2014a). Only nonsea-salt ions were taken into consideration. In addition, the load of $\mathrm{HCO}_{3}{ }_{3}$, resulting from the contribution of atmospheric $\mathrm{CO}_{2}$ in the weathering of limestones and aluminosilicates, was included. The determined value of chemical denudation

Table 4. Load of dissolved matter discharged from the river catchments in the area of Kaffiøyra plain

\begin{tabular}{|c|c|c|c|c|}
\hline \multirow{2}{*}{ Catchment } & Total & Crustal & Atmospheric & Marine \\
\cline { 2 - 5 } & \multicolumn{3}{|c|}{$\mathrm{t} \mathrm{km}^{-2} \mathrm{~d}^{-1}$} \\
\hline CT-1 & 0.115 & 0.069 & 0.044 & 0.002 \\
\hline CT-2 & 0.194 & 0.128 & 0.062 & 0.004 \\
\hline CT-3 & 0.326 & 0.207 & 0.106 & 0.011 \\
\hline
\end{tabular}


for non-glacierized catchments CT- 1 and CT-2 is 0.069 and $0.128 \mathrm{t} \mathrm{km}^{-2} \mathrm{~d}^{-1}$, respectively. It is low compared to other non-glacierized catchments of Spitsbergen (Krawczyk, Pettersson 2007; Chmiel et al. 2011; Szpikowski et al. 2014a), where it fell into the range of $0.128-0.572 \mathrm{t} \mathrm{km}^{-2} \mathrm{~d}^{-1}$. Chemical denudation in CT-3 glacierized catchment was $0.207 \mathrm{t} \mathrm{km}^{-2} \mathrm{~d}^{-1}$. Compared to values from other glacierized catchments (e.g. Krawczyk, Bartoszewski $2008-0.653 \mathrm{t} \mathrm{km}^{-2} \mathrm{~d}^{-1}$, Szpikowski et al. 2014a - 0.689-1.314 t km-2 $\mathrm{d}^{-1}$ ), chemical denudation in CT-3 can be described as low. An intensity of denudation processes in the analysed catchments depends on the amount of water circulating in geoecosystems. A small outflow from CT-1 and CT-2 results in low values of chemical denudation. In contrast, in the CT-3 outflow, a very high contribution of waters from the Waldemarbreen ablation decides about a higher value of chemical denudation than in CT-1 and CT-2.

The obtained data, although represent only the summer period, allow to estimate the volume of annual chemical denudation. Based on the mean daily air temperature, the length of ablation season in the Kaffiøyra plain in 2004 was determined as 90 days (with mean daily air temperature $>0^{\circ} \mathrm{C}$ ) After taking into account this period of hydrological activity, chemical denudation in CT-1, CT-2 and CT-3 was $6.2,11.5$ and $18.7 \mathrm{t} \mathrm{km}^{-2} \mathrm{a}^{-1}$, respectively.

\section{Conclusions}

A diversified mineralization of waters circulating in the investigated catchments was found: from $144 \mathrm{mg} \mathrm{dm}^{-3}$ (CT-3 catchment) to $249 \mathrm{mg}$ $\mathrm{dm}^{-3}$ (CT-1 catchment). The hydrogeochemical type of waters is as follows: $\mathrm{HCO}_{3}^{-}-\mathrm{SO}_{4}^{2-}-\mathrm{Ca}^{2+}-$ $\mathrm{Mg}^{2+}$. A high content of bicarbonates in these waters suggests the presence of significant amount of $\mathrm{CO}_{2}$ of not only biogenic origin. The problem of relatively low release of biogenic $\mathrm{CO}_{2}$ at such high level of carbonate content requires further investigation. At the same time, a low content of $\mathrm{CO}_{2}$ in water was observed, which indicates its maximal use in the process of carbonate rock dissolution. The $\mathrm{HCO}_{3}^{-}$concentration in relation to $\mathrm{pH}$ and $\mathrm{CO}_{2}$ content in the river waters of the Kaffiøyra region clearly suggests that these waters are close to the saturation limit and in spe- cific conditions are capable of depositing $\mathrm{CaCO}_{3}$. Numerous forms of such deposition were found in the carbonate rocks laying on the surface and within the active layer.

The river catchments of the Kaffiøyra plain differ in the intensity of chemical denudation processes, generated by the amount of waters circulating in each of them. The highest value of chemical denudation $\left(0.207 \mathrm{t} \mathrm{km}^{-2} \mathrm{~d}^{-1}\right)$ was found in the glacierized catchment CT-3, due to the large contribution of waters coming from the Waldemarbreen melting. The values in the non-glacierized catchments CT- 1 and CT-2 were much lower: 0,069 and $0.128 \mathrm{t} \mathrm{km}^{-2} \mathrm{~d}^{-1}$, respectively.

High water mineralization and high load of dissolved carbonates and sulphates in the runoff waters from the Kaffiøyra coastal plain, provide a substantial amount of mineral components to Forlandsundet. This is expected to affect the structure and functioning of the littoral zone biocoenoses, including the size of primary production.

We are grateful to the Anonymous Reviewers for their critical reading of the manuscript. Constructive comments greatly improved the paper.

\section{References}

Anisimov O.A., Nelson F.E., 1996. Permafrost distribution in the northern hemisphere under scenarios of climatic change. Global and Planetary Change 14: 59-72.

Bartoszewski S., Michalczyk Z., Magierski J., 1991. The hydrochemical characteristics of the north part of Wedel Jarlsberg Land. Wyprawy Geograficzne na Spitsbergen, UMCS, Lublin: 123-133.

Beylich A.A., 2007. Quantitative studies on sediment fluxes and sediment budgets in changing cold environments - potential and expected benefit of coordinated data exchange and the unification of methods. Landform Analysis 5: 9-10.

Beylich A.A., Lamoureux S.F., Decaulne A., 2007. Coordinated quantitative studies on sediment fluxes and sediment budgets in changing cold environments - examples from three SEDIBUD key test areas in Canada, Iceland and Norway. Landform Analysis 5: 11-12.

Beylich A.A., Lamoureux S.F., Decaulne A., 2011. Developing frameworks for studies on sedimentary fluxes and budgets in changing cold environments. Quaestiones Geographicae 30: 5-18.

Beylich, A.A., Lamoureux S.F., Decaulne A., Dixon J.C., Orwin J.F., Otto J.C., Overeem I., Saemundsson P., Warburton J., Zwoliński, Z., 2010. Sedimentary fluxes and budgets in changing cold environments: the global IAG/ AIG sediment budgets in cold environments (SEDIBUD) programme. Geografiska Annaler, Series A, Physical Geography 92A(2): 151-153. 
Bring A., Destouni G., 2009. Hydrological and hydro-chemical observation status in the pan-Arctic drainage basin. Polar Research 28: 327-338.

Brykała D., Araźny A., 2002. Wpływ warunków meteorologicznych na kształtowanie się odpływu powierzchniowego na lodowcu Waldemara (NW Spitsbergen) latem 1997 roku (The impact of meteorological conditions on runoff from the surface of the Waldemarbreen in summer 1997). Problemy Klimatologii Polarnej 10: 139-158.

Chmiel S., Bartoszewski S., Gluza A., Siwek K., Zagórski P., 2007. Physicochemical characteristics of land waters in the Bellsund region (Spitsbergen). Landform Analysis 5: 13-15.

Chmiel S., Bartoszewski S., Siwek K., 2011. Chemical denudation rates in the Wydrzyca catchment (Bellsund, Spitsbergen). Annales Universitate Mariae Curie-Skłodowska 66: 115-128.

Chmiel S., Bartoszewski S., Siwek K., Sposób J., 2012. Chemical and mechanical denudation rates in the Scott River catchment (Svalbard) during the summer season 2005. Permafrost and Periglacial Processes 18: 337-350.

Christensen T., 1991. Arctic and sub-Arctic soil emissions: possible implications for global climate change. Polar Record 27: 205-210.

Christensen T.R., Michelsen A., Jonasson S., Schmidt I.K., 1997. Carbon dioxide and methane exchange of a subarctic heath in response to climate change related environmental manipulations. Oikos 79: 34-44.

Cooper R.J., Wadham J.L., Tranter M., Hodgkins R., Peters N.E., 2002. Groundwater chemistry in the active layer of the proglacial zone, Finsterwalderbreen, Svalbard. Journal of Hydrology 269: 208-223.

Dolnicki P., Grabiec M., Puczko D., Gawor Ł., Budzik T., Klementowski J. 2013. Variability of temperature and thickness of permafrost active layer at coastal sites of Svalbard. Polish Polar Research 34(4): 353-374.

Dragon K., Marciniak M., 2010. Chemical composition of groundwater and surface water in the Arctic environment (Petuniabukta region, central Spitsbergen). Journal of Hydrology 386: 160-172.

Dziadowiec H., Gonet S., Plichta W., 1994. Properties of humic acids of Arctic tundra soils in Spitsbergen. Polish Polar Research 15: 71-81.

Elvebakk A., Prestrud P. (eds), 1996. A catalogue of Svalbard plants, fungi, algae and cyanobacteria. Norsk Polarinstitutt, Skrifter 198.

Elvebakk A., Elven R., Razzhivin V.Y., 1999. Delimitation, zonal and sectorial subdivision of the Arctic for the Panarctic Flora Project. In: I. Nordal, V.Y. Razzhivin (eds), The species concept in the High North - A Panarctic Flora Initiative. The Norwegian Academy of Science and Letters, Oslo, NO, 375-386

Gerstenhauer A., 1969. Offene Fragen der klimagenetichen Karstgeomorphologie. Der Einfluss der $\mathrm{CO}_{2}$ Konzentration inder Bodenruf auf die Landformung. Studia Geografica 5: 43-51.

Grześ M., Król M., Sobota I., 2009, Submarine evidence of the Aavatsmark and Dahl Glaciers fluctuations in the Kaffiøyra region, NW Spitsbergen. Polish Polar Research 30(2): 143-160.

Gugnacka-Fiedor W., Noryśkiewicz B., 1982a. Rośliny naczyniowe Ziemi Oskara II, Spitsbergen północno-zachodni (Vascular plants from Oscar II Land, North-West Spitsbergen). Acta Univ. N. Copernici, Biologia 24(53): 55-64.
Gugnacka-Fiedor W., Noryśkiewicz B., 1982b. The vegetation of Kaffiøyra, Oscar II Land, NW Spitsbergen. Acta Univ. N. Copernici, Geografia 16(51): 203-238.

Hadač E., 1989. Notes on plant communities of Spitsbergen. Folia Geobotanica et Phytotaxonomica 24: 131-169.

Hjelle A., Piepjohn K., Saalmann K., Ohta Y., Salvigsen O., Thieding F., Dallmann W.K., 1999. Geological maps of Svalbard 1:100,000, sheet A7G Kongsfjorden. Norwegian Polar Institute, Troms $\varnothing$.

Hodson A., Tranter M., Gurnell A., Clark M., Hagen J.O., 2002. The hydrochemistry of Bayelva, a high Arctic proglacial stream in Svalbard. Journal of Hydrology 257: 91-114.

Hodson A., Tranter M., Vatne G., 2000. Contemporary rates of chemical denudation and atmospheric $\mathrm{CO}_{2}$ sequestration in glacier basins: an Arctic perspective. Earth Surface Processes and Landforms 25: 1447-1471.

Humlum O., Instanes A., Sollid L., 2003. Permafrost in Svalbard: a review of research history, climatic background and engineering challenges. Polar Research 22: 191-215.

Jakucs L., 1977. Morphogenetics of karst regions: variants of karst eEvolution. Akademiai Kiado, Budapest.

Jaworski T., 2010. Marine terraces in Kaffiøyra and Hermansenøya (Oscar II Land, NW Spitsbergen). Landform Analysis 14: 25-33.

Jonasson S., Michelsen A., Schmidt I.K., 1999. Coupling of nutrient cycling and carbon dynamics in the Arctic, integration of soil microbial and plant processes. Applied Soil Ecology 11: 135-146.

Kokelj S.V., Burn C.R., 2003. Ground ice and soluble cations in near-surface permafrost, Inuvik, northwest territoriers, Canada. Permafrost and Periglacial Processes 14: 275-289.

Kostrzewski A., Kaniecki A., Kapuściński J., Klimczak R., Stach A., Zwoliński Z., 1989. The dynamics and rate of denudation of glaciated and non-glaciated catchments, central Spitsbergen. Polish Polar Research 10: 317-367.

Kostrzewski A., Rachlewicz G., Zwoliński Z., 2007. Present-day geomorphological activity in the Arctic. Landform Analysis 5: 41-46.

Krawczyk W.E., Bartoszewski S.A., 2008. Crustal solute fluxes and transient carbon dioxide drawdown in the Scottbreen Basin, Svalbard in 2002. Journal of Hydrology 362: 206-219.

Krawczyk W., Pettersson L.E., 2007. Chemical denudation rates and carbon dioxide drawdown in an ice-free polar karst catchment: Londonelva, Svalbard. Permafrost and Periglacial Processes 18: 337-350.

Kuhry P., Dorrepaal E., Hugelius G., Schuur E.A.G., Tarnocai C., 2010. Short communication potential remobilization of belowground permafrost carbon under future global warming. Permafrost and Periglacial Processes 21: 208-214.

Lankauf K.R., 2002. Recesja lodowców rejonu Kaffiøyry (Ziemia Oskara II-Spitsbergen) w XX wieku (Recession of Kaffiøyra region glaciers (Oscar II Land, Svalbard) in the twentieth century). Prace Geograficzne 183: 1-221.

Macioszczyk A., Dobrzyński D., 2007. Hydrogeochemia strefy aktywnej wymiany wód podziemnych (The hydrogeochemistry of the zone of active groundwater exchange). Wydawnictwo Naukowe PWN, Warszawa.

Markowicz M., Pulina M., 1979. Ilościowa pół mikroanaliza chemiczna wód w obszarach krasu węglanowego (Quantitative chemical half microanalysis of water in carbonate karst areas). Pr. Nauk. Uniwersytetu Ślaskiego 289: 1-67.

Mazurek M., Paluszkiewicz R., Rachlewicz G., Zwoliński Z., 2012. Variability of Water Chemistry in Tundra Lakes, 
Petuniabukta Coast, Central Spitsbergen, Svalbard. Scientific World Journal 596516. DOI: 10.1100/2012/596516

Nowak A., Hodson A., 2014. On the biogeochemical response of a glacierized High Arctic watershed to climate change: Revealing patterns, processes and heterogeneity among micro-catchments. Hydrological Processes: DOI: 10.1002/hyp.10263

Plichta W., 1993. Gleby Kaffiøyry, Spitsbergen - szkic monograficzny (Soils of Kaffiøyra - monographic sketch). Uniwersytet Mikołaja Kopernika, Toruń

Przybylak R., Araźny A. 2006. Climatic conditions of the north-western part of Oscar II Land (Spitsbergen) in the period between 1975 and 2000. Polish Polar Research 27(2): 133-152.

Przybylak R., Kejna M., Araźny A. 2011. Air temperature and precipitation changes in the Kaffiøyra region (NW Spitsbergen) from 1975 to 2010. Papers on Global Change, 18: $7-22$

Pulina M., 1984. The effects of cryochemical processes in the glaciers and the permafrost in Spitsbergen. Polish Polar Research 5: 137-163.

Pulina M., 1990. Geomorphological effects of the cryochemical process. Quaestiones Geographicae 13/14: 99-112.

Pulina M., Burzyk J., 2002. Dwutlenek węgla produkowany latem 2001 r. w tundrze zlewni Fugleberget (Hornsund - Spitsbergen) i jego rola $\mathrm{w}$ denudacji chemicznej (Carbon dioxide produced in the summer 2001 in the tundra of Fugleberget catchment (Hornsund - Spitsbergen) and its role in chemical denudation). In: A. Kostrzewski, G. Rachlewicz (eds), Polish Polar Studies, Funkcjonowanie $i$ monitoring geoekosystemów obszarów polarnych. Bogucki Wyd. Nauk., Poznań: 239-254.

Pulina M., Burzyk J., Burzyk M., 2003. Carbon dioxide in the tundra soils of SW Spitsbergen and its role in chemical denudation. Polish Polar Research 24: 243-260.

Pulina M., Krawczyk W., Pereyma J., 1984. Water balance and chemical denudation in the unglaciated Fugleberget basin SW Spitsbergen. Polish Polar Research 5: 183-205.

Raich J.W., Schlesinger W.H., 1992. The global carbon dioxyde flux in soil respiration and its relationship to vegetation and climate. Tellus 44B: 81-99.

Rachlewicz G., Burzyk M., Samołyk M., Szczucińska A.M., Szczuciński W., 2007. Particulate and dissolved matter transfer in small High-Arctic non-glaciated basins - Central Spitsbergen. 2nd SEDIBUD Workshop, Abisko-Sweden, Abstract volume: 44 .

Sharp M., Tranter M., Brown G., Skidmore M., 1995. Rates of chemical denudation and $\mathrm{CO}_{2}$ drawdown in a glacier-covered alpine catchment. Geology 23: 61-64.

Shaver G.R., Billings W.D., Chapin III F.S., Giblin A.E., Nadelhoffer K.J., Oechel W.C., Rastetter E.B., 1992. Global change and the carbon balance of Arctic ecosystems. BioScience 42: 433-441.

Sobota I., 2013a. Changes in dynamics and runoff from the High Arctic glacial catchment of Waldemarbreen, Svalbard, Geomorphology, doi:10.1016/j.geomorph.2013.04.001.

Sobota I., 2013b. Wspótczesne zmiany kriosfery pótnocno-zachodniego Spitsbergenu na przykładzie regionu Kaffiøyry (Contemporary changes in the cryosphere of the north-west- ern Spitsbergen; Kaffiøyra region case study). Wyd. Nauk. UMK, Torun.

Sobota I., 2014. Changes in dynamics and runoff from the High Arctic glacial catchment of Waldemarbreen, Svalbard. Geomorphology 212: 16-27.

Sobota I., Araźny A., Barcikowski A., Birkenmajer K., Grześ M., Gugnacka-Fiedor W., Lankauf K.R., Plichta W., Przybylak R., Zubel P., 2013. Geographical environment in the vicinity of the Nicolaus Copernicus University Polar Station - Kaffiøyra. In: Z. Zwoliński, A. Kostrzewski, M. Pulina (eds), Ancient and modern geoecosystems of Spitsbergen. Bogucki Wyd. Nauk., Poznań: 181-204.

Sobota I., Lankauf K.R., 2010. Recession of Kaffiøyra region glaciers, Oscar II Land, Svalbard. Bulletin of Geography Physical Geography Series 3: 27-45.

Sobota I., Nowak M., 2012. Dynamika odpływu ze zlodowaconej zlewni rzeki Waldemara (NW Spitsbergen) w sezonach letnich 2009-2011 (The dynamics of runoff from the Waldemarbreen glacierized river catchment (NW Spitsbergen) in summer seasons 2009-2011). Problemy Klimatologii Polarnej 22: 57-68.

Sobota I., Nowak M., 2014. Changes in the dynamics and thermal regime of the permafrost and active layer of the High Arctic coastal area in North-West Spitsbergen, Svalbard. Geografiska Annaler, Series A, Physical Geography 96 (2): 227-240.

Song L., Fuyuan L., 2001. Distribution of $\mathrm{CO}_{2}$ in soil air affected by vegetation in the Shilin National Park. Acta Geologica Sinica 73: 288-293.

Stumm W., Morgan J., 1996. Aquatic chemistry, third ed. John Wiley \& Sons, New York.

Szczepanik W., 1993. Reżim wybranych rzek Kaffiøyry (Ziemia Oskara II, NW Spitsbergen) w okresie lata polarnego. Acta Universitatis Nicolai Copernici, Geografia, 24, 82: 55-146.

Szpikowski J., Szpikowska G., Zwoliński Z., Kostrzewski A., 2014a. Magnitude of fluvial transport and denudation in a non-glacierized catchment in a polar zone, Central Spitsbergen. Geografiska Annaler, Series A, Physical Geography 96 (4): 447-464.

Szpikowski J., Szpikowska G., Zwoliński Z., Rachlewicz G., Kostrzewski A., Marciniak M. Dragon K., 2014b. Character and rate of denudation in a High Arctic glacierized catchment (Ebbaelva, Central Spitsbergen). Geomorphology 218: 52-62.

Turner J., Marshall G.J., 2011. Climate change in the polar regions. Cambridge: Cambridge University Press.

Woo M., Lewkowicz A.G., Rouse W.R., 1992. Response of the Canadian permafrost environment to climatic change. Physical Geography 13: 287-317.

Zwoliński Z., Mazurek M., Paluszkiewicz R., Rachlewicz G., 2008. The matter fluxes in the geoecosystem of small tundra lakes, Petuniabukta coast, Billefjorden, Central Spitsbergen. Zeitschrift Fur Geomorphologie 52(1): 79-101. DOI: 10.1127/0372-8854/2008/0052S1-0079

Zwoliński Z., Szpikowski J., Wiśniewska K., 2012. Provenance of surface waters on the western coast of Admiralty Bay, King George Island, Antarctica. Zeitschrift Fur Geomorphologie 56(1): 123-141. DOI: 10.1127/03728854/2012/S-00076 